\title{
The Impact of Senders' Identity to the Acceptance of Electronic Word-of-Mouth of Consumers in Vietnam
}

\author{
Hung DINH*, Thanh Ha DOAN** \\ Received: November 16, 2019 Revised: December 11, 2019 Accepted: December 18, 2019
}

\begin{abstract}
Studies related to Electronic Word-of-Mouth (eWOM) show that the acceptance of eWOM information is an important factor in customer purchase decisions. When consumers accept eWOM information, they tend to use that information in considering before making purchase decisions. In Viet Nam, there are few studies about eWOM information, especially on the acceptance of eWOM information. Research is conducted to test the influence of consumers on the perception of the senders' identity to the acceptance of online reviews (a kind of eWOM) in Viet Nam - a case study in Ho Chi Minh City. Using adjustment techniques, inspecting the scales and a theoretical model represent the relationship among the influential factors. The research is based on a sample of 522 consumers who use the Internet to search for product reviews before buying and used Structural Equation Modeling (SEM) to test the relationships among the variables. The research results show that the scales of the variables: Message Quality, Source Credibility, Perceived Message Usefulness, Perceived Senders' Identity, Perceived Message Credibility, Message Acceptance attain the validity and reliability in the research. The research contributes to the understanding of the determinants that influence the acceptance of eWOM information, which are informational factors, and factors related to consumer skepticism.
\end{abstract}

Keywords: Message Quality, Message Usefulness, Message Credibility, Message Acceptance, Consumer Skepticism

JEL Classification Code: C12, M30, M31, M37

\section{Introduction}

Studies related to Electronic Word-of-Mouth (eWOM) show that the acceptance of eWOM information is an important factor in customer purchase decisions (Sussman \& Siegal, 2003; Hussain, Guangju, Jafar, Ilyas, Mustafa, \& Jianzhou, 2018). When consumers accept eWOM information, they tend to use that information in considering before making purchase decisions (Fan, Miao, Fang, \& Lin, 2013). However, marketers tend to use fake eWOM (eWOM is not created by a real consumer or a potential consumer) to influence consumer buying decisions (Zhao, Yang, S., Narayan, V., \& Zhao, 2013;

${ }^{*}$ First Author and Corresponding Author. PhD Candidate, Department of Graduate, Lac Hong University, Viet Nam [Postal Address: No. 10, Huynh Van Nghe Street, Buu Long Ward, Bien Hoa City, 810000, Viet Nam]; HCM City University of Foreign Languages and Information Technology, Viet Nam.

Email: dinhhung621@huflit.edu.vn

** Banking University of Ho Chi Minh City, Viet Nam.

Email: hadt@buh.edu.vn

$\odot$ Copyright: Korean Distribution Science Association (KODISA)

This is an Open Access article distributed under the terms of the Creative Commons Attribution NonCommercial License (https://creativecommons.org/licenses/by-nc/4.0/) which permits unrestricted noncommercial use, distribution, and reproduction in any medium, provided the original work is properly cited.
Cavazza \& Guidetti, 2014; Munzel, 2016; Tamar, 2016; Zhang, Ko, \& Carpenter, 2016; Nakayama \& Wan, 2017; Ahmad \& Sun, 2018) - the presence of fake eWOM has led to consumers skepticism and eroding their confidence when using eWOM information in making buying decisions (Ahmad \& Sun, 2018).

Furthermore, eWOM information is fundamentally different from traditional Word-of-Mouth (WOM) in that the sender and recipient may not know each other completely (Hennig-Thurau \& Walsh, 2003; Huete-Alcocer, 2017) then one of the factors consumers are skeptical about is senders' identity - the sender is an actual consumer or a marketing staff of a company; the senders have used their real names or pseudonym in product reviews; do they only used one pseud or multiple pseudonyms for product reviews. However, there are few studies focus on exploring the aspect of consumer skepticism in the acceptance of eWOM information. Therefore, this study is carried out to examine "The effects of senders' identity to the acceptance of electronic Word-of-Mouth (eWOM) of consumers in Viet Nam - Case Study in Ho Chi Minh City" to verify the hypothesis. 
The paper is organized as follows: Section 1 introduces research issues; Section 2 presents the literature review; Section 3 presents the proposed model; Section 4 presents research data and methods; Section 5 presents the results of empirical research; the final section summarizes the findings and implications.

\section{Literature Review}

\subsection{Social Communication Theory}

According to the theory of Social Communication Theory (Hovland, 1948), communication is the process in which the sender (Communicator) transmits messages (Stimuli) in order to change the behavior of the message recipient (Communicatee), the result of the change is called responsiveness (Response). The Social Communication Theory shows that the process of social communication consists of the interaction of four elements: Communicator, Stimuli, Communicatee, and Response. The theory is used to investigate the cause of accepting eWOM information from consumers and in this study, it is used as a reference framework.

\subsection{Theory of Reasoned Action (TRA) and Theory of Planned Behavior (TPB)}

Theory of Reasoned Action - TRA and Theory of Planned Behavior - TPB proposed by Ajzen (1991) to study the relationship between belief, attitude, intention, and behavior. These two theories prove that a behavior can be predicted or explained by the intention to perform that behavior. Intents are assumed to include motivational factors that influence behavior and are defined as the degree of effort the individual attempts to perform the behavior.

The most important point of these theories for the problem of the acceptance eWOM information is belief factors - the result of the influence of background factors. Researchers on the subject of Information Acceptance are based on this and the Social Communication Theory to interpret and build their research models, such as Venkatesh and Bala (2008); Sussman and Siegal (2003); Shen, Cheung, and Lee (2013); Erkan and Evans (2016); Hussain et al. (2017); Wang (2018).

\subsection{Information Adoption Model - IAM}

As proposed by Sussman and Siegal (2003), the authors argued that acceptance is, in fact, explained by the Technology Acceptance Model - TAM (Venkatesh \& Bala, 2008) (i.e., based on the Reasoning Action Theory - TPB
(Ajzen, 1991)) are incomplete as they focus on information systems and on the use of personal computers. It is not possible to explain the process of accepting information. The Information Adoption Model - IAM (Sussman \& Siegal, 2003) is the result of combining the TAM model and the Elaboration Likelihood Model - ELM (Petty \& Cacioppo, 1986).

\section{Proposed Model}

\subsection{Informational Influences}

The current research model based on the IAM model of Sussman and Siegal (2003) to assess the effect of informational factors on the acceptance of eWOM information. By this model, the quality of message (Argument quality) is assigned to the central flow and Source credibility is assigned to the peripheral flow, and construct Usefulness is considered as a mediator variable. Therefore, in the proposed model (Figure 1) the authors reused 3 research hypotheses as follows:

H1: Message Quality has a positive impact on Perceived Message Usefulness $\mathrm{H} 1(+)$

H2: Source Credibility has a positive impact on Perceived Message Usefulness $\mathrm{H} 2(+)$

H3: Perceived Message Usefulness has a positive impact on Message Acceptance H3(+)

\subsection{Perceived Senders' Identity of Consumers}

Because marketers recognize the benefits of eWOM information for consumers, they tend to abuse this kind of information to influence consumers in buying decisions. According to a study by Luca and Zervas (2016), about 16\% of restaurant reviews on the rating page of US restaurants www.Yelp.com are fake and up to $15 \%$ of all online reviews are fake (Tamar, 2016). Therefore, fake eWOM has been eroding consumer confidence in this kind of information (eWOM). One of the few studies on eWOM related to the concept of skepticism wad conducted by Sher and Lee (2009). In this study, the authors used the ELM model to examine the effect of construct skepticism on the relationship between constructs Argument Quality and Argument Quantity to the Consumer's Buying Intention in case the consumer has different levels of doubt.

The current research model proposes an expanding approach of the IAM model to assess the effect of informational factors and the identity of the sender on perceiving the credibility of the information and accordingly the acceptance eWOM information. The causal relationship between perceived senders' identity construct 
and perceived messages' credibility is inherited from the work of Cheung, Luo, Sia, and Chen (2009). In the proposed model, the perceived senders' identity construct is measured using the scale of Zhang, Ko, and Carpenter (2016). Based on the mentioned reasoning, the authors propose two more research hypotheses as follows:

H4: Perceived Senders' Identity has a negative impact on Perceived Message Credibility H4(-)

H5: Perceived Message Credibility has a positive impact on Message Acceptance H5(+)

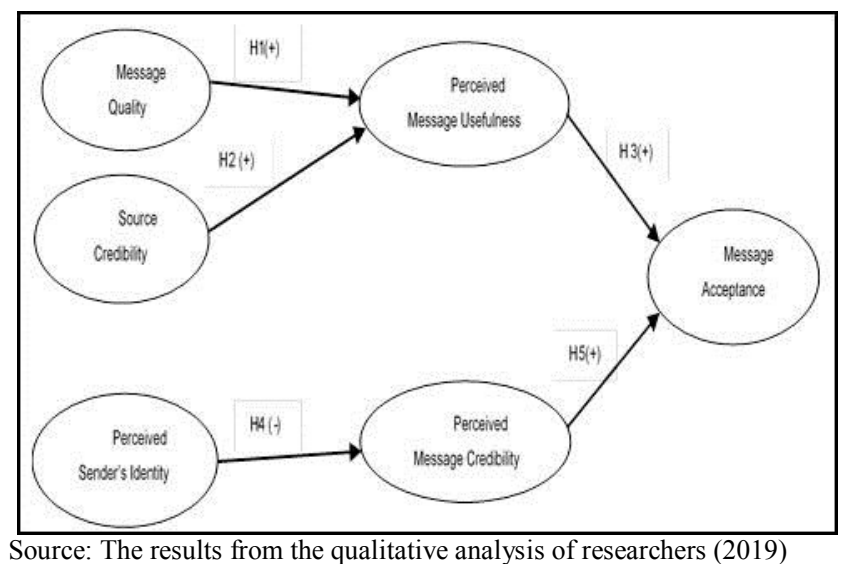

Figure 1: Model of the impact of perceived senders' identity

\section{Research Data and Methods}

\subsection{Research Data}

The participants in the survey are consumers who use the Internet to search for product reviews before buying in Viet Nam. Using Message Quality, Source Credibility and Message Acceptance scales of Chou, Wang, and Tang (2015), Perceived Usefulness scale of Cheung, Lee, and Rabjohn (2008), Perceived Senders' Identity scale of Zhang, Ko, and Carpenter (2016), and Perceived Message Credibility scale of Cheung et al. (2009).

\subsection{Research Methods}

The quantitative analysis using software IBM SPSS version 22 and IBM SPSS AMOS version 20. The analysis is the following steps: Testing the scale using Cronbach's Alpha reliability testing and Exploratory Factor Analysis (EFA); Testing the measurement model using Confirmatory Factor Analysis (CFA) and testing the theoretical model using Structural Equation Modeling (SEM) based on the collected data.

\section{Research Results}

\subsection{Representative Sample}

Samples were selected according to a convenient sampling method. Data is collected via an online survey for 8 weeks. The result obtained 522 questionnaires answered satisfactorily. The collected data is processed and the statistical description is as follows (Table 1):

Table 1: Descriptive Statistics

\begin{tabular}{|c|c|c|c|}
\hline \multicolumn{2}{|c|}{ Demographic Feature } & Frequency & Percentage \\
\hline \multirow{3}{*}{ Gender } & Male & 285 & 54.6 \\
\cline { 2 - 4 } & Female & 227 & 43.5 \\
\cline { 2 - 4 } & Unknown & 10 & 1.9 \\
\hline \multirow{2}{*}{ Age } & $18-23$ & 315 & 60.3 \\
\cline { 2 - 4 } & $24-35$ & 207 & 39.7 \\
\hline
\end{tabular}

Source: Results from the data process of researchers (2019)

\subsection{Pre-Test for the Questionnaires}

\subsubsection{Cronbach's Alpha Results}

Research use the scales of Chou, Wang and Tang (2015) for 3 constructs Message Quality (including 3 observable variables, encoded from CHATLUONG1 to CHATLUONG3), Source Credibility (including 3 observable variables, encoded from DOTINCAY1 to DOTINCAY3) and Message Acceptance (including 4 observable variables, encoded from CHAPNHANEWOM1 to CHAPNHANEWOM4); the scale of Cheung, Lee, and Rabjohn (2008) for construct Perceived Usefulness (including 3 observable variables, encoded from CN_HUUDUNG1 to CN_HUUDUNG3); the scale of Zhang, Ko, and Carpenter (2016) for construct Perceived Senders' Identity (including 3 observable variables, encoded from DANHTINH1 to DANHTINH3); the scale of Cheung et al. (2009) for construct Perceived Message Credibility (including 3 observable variables, encoded from CN_DOTINCAY1 to CN_DOTINCAY3).

Table 2: Summarizes the results of Cronbach's Alpha testing

\begin{tabular}{|c|c|c|}
\hline Scales & $\begin{array}{c}\text { Cronbach's } \\
\text { Alpha }\end{array}$ & $\begin{array}{c}\text { The Minimum of } \\
\text { Corrected Item- } \\
\text { Total Correlation }\end{array}$ \\
\hline Message Quality & 0.827 & 0.653 \\
\hline Source Credibility & 0.929 & 0.805 \\
\hline Perceived Usefulness & 0.937 & 0.862 \\
\hline Perceived Senders' Identity & 0.923 & 0.820 \\
\hline $\begin{array}{c}\text { Perceived Message } \\
\text { Credibility }\end{array}$ & 0.919 & 0.810 \\
\hline Message Acceptance & 0.859 & 0.714 \\
\hline
\end{tabular}

Source: Results from the data process of researchers (2019)

The results of the pre-test the questionnaires show that constructs Message Quality, Source Credibility, Perceived Senders' Identity, Perceived Usefulness, Perceived 
Message Credibility and Message Acceptance (excluded the observable variable CHAPNHANEWOM3 of substandard quality is rejected) have Cronbach's Alpha between 0.60 to 0.95 and the Corrected item-total Correlation greater than 0.3 (Table 2), so all attained the reliability and are used for EFA analysis.

\subsubsection{EFA analysis results}

The EFA analysis results show that 5 factors are extracted explaining $78.556 \%(>50 \%)$ of the variance with eigenvalue at 1.729 , so all observable variables used in the CFA analysis.

\subsection{Test of the Measurement Model: CFA analysis results}

The CFA analysis results show that chi- square is 378.133 with $\mathrm{df}=120, \mathrm{p}=0.000 . \mathrm{Cmin} / \mathrm{df}=3.151<5$, meet the requirement for compatibility. TLI $=0.950>0.9$, $\mathrm{CFI}=0.961>0.9$, GFI $=0.922>0.9$ and $\mathrm{RMSEA}=0.065$ $<0.08$ are all suitable. Figure 2 presents the CFA results for the standardized model:

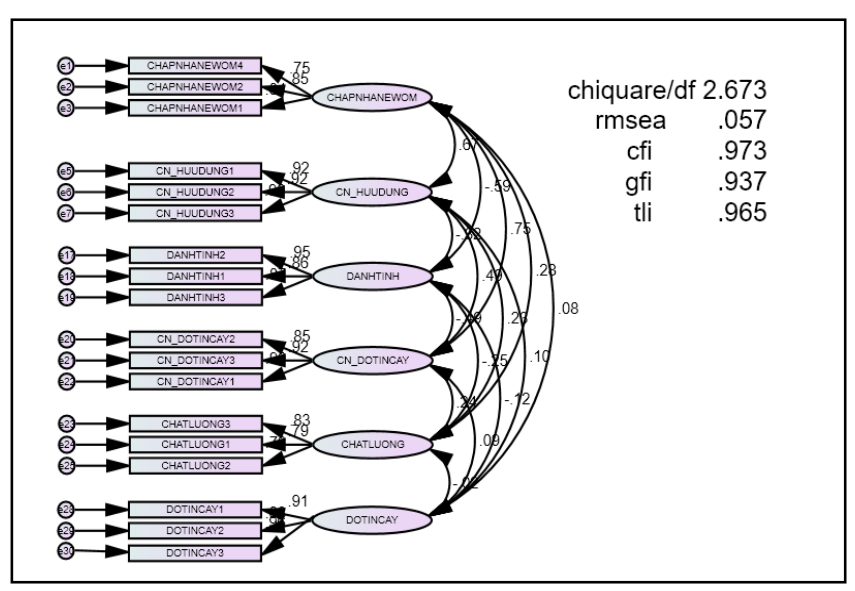

Source: Results from the data process of researchers (2019)

Figure 2: CFA results for the standardized model

\section{Other indexes:}

Convergent validity: the CFA results show that the AVE coefficients (Average Variance Extracted) of all constructs are $>0.5$ so the scale attain convergent validity.

Discriminant validity: the CFA results show that the square root of AVE greater than correlation coefficients of all constructs, so all constructs attain discriminant validity.

Unidimentionality: the CFA results show that the unidimensionality is attained because all observable variables have factor loading greater than 0.6.

Reliability: Reliability test results through the following indexes: (i) composite reliability, (ii) total variance extracted and (iii) Cronbach's Alpha testing. The CFA results show that all the scales have composite reliability $>$ 0.5 , total variance extracted $>0.5$, Cronbach's Alpha $>0.5$, so the scales attain reliability.

The summarized results of scales testing present in Table 3 .

Table 3: The summarized results of scales testing

\begin{tabular}{|c|c|c|c|c|c|}
\hline \multirow{2}{*}{ Scales } & \multirow{2}{*}{$\begin{array}{l}\text { No. of } \\
\text { items }\end{array}$} & \multicolumn{2}{|c|}{$\begin{array}{l}\text { Reliability } \\
\text { Statistics }\end{array}$} & \multirow{2}{*}{$\begin{array}{l}\text { Variance } \\
\text { Extracted }\end{array}$} & \multirow{2}{*}{$\begin{array}{l}\text { Vali- } \\
\text { dity }\end{array}$} \\
\hline & & $\begin{array}{l}\text { Cronbach } \\
\text { 's Alpha }\end{array}$ & $\begin{array}{l}\text { Com- } \\
\text { posite }\end{array}$ & & \\
\hline $\begin{array}{l}\text { Message } \\
\text { Quality }\end{array}$ & 3 & 0.827 & 0.828 & 0.617 & \\
\hline $\begin{array}{c}\text { Source } \\
\text { Credibility }\end{array}$ & 3 & 0.929 & 0.930 & 0.816 & A \\
\hline $\begin{array}{l}\text { Perceived } \\
\text { Usefulness }\end{array}$ & 3 & 0.937 & 0.938 & 0.834 & $\begin{array}{l}\mathrm{C} \\
\mathrm{C}\end{array}$ \\
\hline $\begin{array}{l}\text { Perceived } \\
\text { Senders' } \\
\text { Identity }\end{array}$ & 3 & 0.923 & 0.925 & 0.805 & $\begin{array}{l}\mathrm{E} \\
\mathrm{P} \\
\mathrm{T}\end{array}$ \\
\hline $\begin{array}{l}\text { Perceived } \\
\text { Message } \\
\text { Credibility }\end{array}$ & 3 & 0.919 & 0.920 & 0.793 & $\begin{array}{l}\mathrm{E} \\
\mathrm{D}\end{array}$ \\
\hline $\begin{array}{c}\text { Message } \\
\text { Acceptance }\end{array}$ & 3 & 0.859 & 0.858 & 0.617 & \\
\hline
\end{tabular}

Source: Results from the data process of researchers (2019)

\subsection{Test for the Causal Model: SEM analysis results}

Using the Structural Equation Modeling (SEM) to test the impact of Perceived Senders' Identity, Message Quality, Source Credibility on Message Acceptance in Viet Nam. The results present in Table 4 and Figure 3.

Table 4: The results of testing the causal relations among constructs (Standardized)

\begin{tabular}{|c|c|c|c|c|}
\hline $\begin{array}{c}\text { Hypo- } \\
\text { theses }\end{array}$ & Causal relations & $\begin{array}{c}\text { Esti- } \\
\text { mation }\end{array}$ & $\begin{array}{c}\text { p- } \\
\text { value }\end{array}$ & $\begin{array}{c}\text { Conclu- } \\
\text { sion }\end{array}$ \\
\hline H1 & $\begin{array}{c}\text { CN_HUUDUNG } \\
\text { CHATLUONG }\end{array}$ & 0.247 & 0.000 & Accepted \\
\hline H2 & $\begin{array}{c}\text { CN_HUUDUNG } \leftarrow \\
\text { DOTINCAY }\end{array}$ & 0.107 & 0.000 & Accepted \\
\hline H3 & $\begin{array}{c}\text { CHAPNHANEWOM } \\
\leftarrow \text { CN_HUUDUNG }\end{array}$ & 0.443 & 0.000 & Accepted \\
\hline H4 & $\begin{array}{c}\text { CN_DOTINCAY } \leftarrow \\
\text { DANHTINH }\end{array}$ & -0.509 & 0.000 & Accepted \\
\hline H5 & $\begin{array}{c}\text { CHAPNHANEWOM } \\
\leftarrow \text { CN_DOTINCAY }\end{array}$ & 0.640 & 0.000 & Accepted \\
\hline
\end{tabular}

Source: Results from the data process of researchers (2019)

The SEM analysis results show that causal relations are statistically significant. Thus, all hypotheses are accepted. The causal relation of Perceived Senders' Identity and Perceived Message Credibility has a negative correlation (correlation coefficient $<0$ ), but all the others have a positive correlation (estimation correlation coefficients $>0$ ). Furthermore, the SEM analysis results also show that $\mathrm{R}$ square of 0.629 is greater than a similar study of Cheung, Lee and Rabjohn (2008) with R square of 0.460 , indicating 
that the proposed model explained more variance of the Message Acceptance construct than the model of Cheung, Lee, and Rabjohn (2008) by adding the construct of Perceived Senders' Identity to the IAM model of Sussman and Siegal (2003). Figure 3 presents the SEM results for the standardized model.

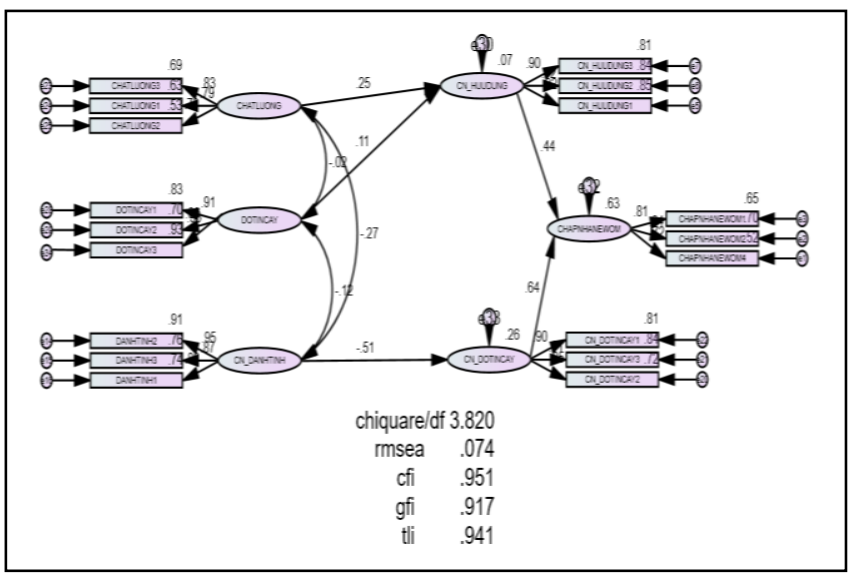

Source: Results from the data process of researchers (2019)

Figure 3: SEM results for the standardized model

\section{Discussion and Implications}

\subsection{Discussion}

Perceived Senders' Identity" (DANHTINH) has a direct impact on the "Perceived Message Credibility" (CN_DOTINCAY) with $\beta=-0.509$, which proves that perceived credibility of message strongly influenced by the skepticism about the transparency of senders' identity. In other words, perceived senders' identity has a strong impact on reducing the perceived credibility and thereby reducing message acceptance, suggesting that consumers appreciate throughout the identity of the senders. This is also a new feature of this research compared to extant studies. Next is the construct "Message Quality" (CHATLUONG) has a relatively influence on the "Perceived Usefulness" (CN_HUUDUNG) with $\beta=0.247$, which proves that perceived usefulness is quite affected by the message quality. That's mean message quality has a quite impact on increasing the perceived usefulness, through which increasing message acceptance; shows that consumers are also interested in the quality aspect of the message, which is consistent with similar studies, such as those of Shen et al. (2013), and Tseng and Wang (2016).

Besides, the regression coefficient of message quality (CHATLUONG) indirectly impact on message acceptance (CHAPNHANEWOM): message quality $\mathrm{x}$ perceived usefulness $=0.109$. This shows that when other factors do not change, message quality increases 1, message acceptance increases 0.109 . The regression coefficient of perceived senders' identity (DANHTINH) indirectly impact on message acceptance (CHAPNHANEWOM): perceived senders' identity x perceived message credibility $=-0.326$. This shows that when other factors do not change, the perceived senders' identity increases 1 , message acceptance decreases 0.326. Similarly, the source credibility and perceived usefulness increase 1, message acceptance increases 0.048 .

SEM results show that message quality, source credibility has a positive impact on perceived usefulness, so the hypotheses $\mathrm{H} 1, \mathrm{H} 2$ are accepted; perceived usefulness has a positive impact on message acceptance, so hypothesis H3 are accepted; perceived senders' identity has a negative impact on perceived message credibility, so hypothesis H4 is accepted; perceived message credibility has a positive impact on message acceptance, so hypothesis H5 are accepted;

In conclusion, the research results are consistent with results of previous studies in the impact of message quality, source credibility on message acceptance through mediator perceived usefulness such as Cheung, Lee, and Rabjohn (2008), Shen, Cheung, and Lee (2013), Tseng and Wang (2016); message quality and source credibility increase the ability to accept eWOM information of consumers. Furthermore, the addition of Perceived Senders' Identity (DANHTINH) and Perceived Message Credibility (CN_DOTINCAY) to IAM model of Sussman and Siegal $(200 \overline{3})$ - to reflect the impact of the skepticism to the acceptance of eWOM information - shows that this impact has a significant statistics, thereby explaining more the variation of message acceptance comparing to previous studies.

\subsection{Implications}

This study helps businesses understand the important factors that influence the acceptance of eWOM information, which are informational factors (Message Quality and Source Credibility), a factor related to the consumer skepticism (Perceived Senders' Identity). These factors indirectly impact on the acceptance of eWOM information through mediators Perceived Usefulness and Perceived Message Credibility.

When consumers accept eWOM information, they might be able to use this kind of information as a basis for their buying decisions. Therefore, businesses might be able to develop eWOM communication as an effective marketing tool in the form of allowing consumers submitting their voice about products, services; send comments; write reviews ... on the company's website. Furthermore, businesses might associate with other independent websites 
specializing in review products, services to invite them trying products, services. This gives consumers a chance to have products' information objectively from various sources before making a purchase decision. Besides, businesses might also link their websites with some social websites, so that businesses can collect consumers' feedback on these websites.

The most important thing businesses should know that is not interfering with the interaction process between consumers because of the fact that consumers tend to trust the information provided by other consumers rather than the information provided by a seller or a marketer - due to the nature of the Word-of-Mouth in general and the electronic Word-of-Mouth in particular considered by consumers as an advice rather than an offer or advertisement (Hennig-Thurau, Gwinner, Walsh, \& Gremler, 2004) and consumers believe in such advice. The experience gained during the research is the basis for the completion of research activities on the impact of eWOM information on the acceptance eWOM information and accordingly the intention of consumers to purchase decisions in future studies.

\section{References}

Ahmad, W., \& Sun, J. (2018). Modeling consumer distrust of online hotel reviews. International Journal of Hospitality Management, 71, 77-90.

https://doi.org/10.1016/j.ijhm.2017.12.005

Ajzen, I. (1991). The theory of planned behavior. Organizational Behavior and Human Decision Processes, 50(2), 179-211. https://doi.org/10.1016/0749-5978(91)90020-T

Cavazza, N., \& Guidetti, M. (2014). Fake online reviews: A study on eWOM influence when suspicions arise. Psicologia Sociale, 9(1), 71-81. https://doi.org/10.1482/76369

Cheung, C. M. K., Lee, M. K. O., \& Rabjohn, N. (2008). The impact of electronic word-of-mouth. Internet Research, 18(3), 229-247. https://doi.org/10.1108/10662240810883290

Cheung, M. Y., Luo, C., Sia, C. L., \& Chen, H. (2009). Credibility of Electronic Word-of-Mouth: Informational and Normative Determinants of On-line Consumer Recommendations. International Journal of Electronic Commerce, 13(4), 9-38. https://doi.org/10.2753/JEC1086-4415130402

Chou, C. H., Wang, Y. S., \& Tang, T. I. (2015). Exploring the determinants of knowledge adoption in virtual communities: A social influence perspective. International Journal of Information Management, 35(3), 364-376. https://doi.org/10.1016/j.ijinfomgt.2015.02.001

Erkan, I., \& Evans, C. (2016). The influence of eWOM in social media on consumers' purchase intentions: An extended approach to information adoption. Computers in Human Behavior, 61(October), 47-55. https://doi.org/10.1016/j.chb.2016.03.003

Fan, Y.-W., Miao, Y.-F., Fang, Y.-H., \& Lin, R.-Y. (2013). Establishing the Adoption of Electronic Word-of-Mouth through Consumers' Perceived Credibility. International Business Research, 6(3), 58-65. https://doi.org/10.5539/ibr.v6n3p58

Hennig-Thurau, T., \& Walsh, G. (2003). Electronic wordof-mouth: Motives for and consequences of reading customer articulations on the Internet. International Journal of Electronic Commerce, 8(2), 51-74. https://doi.org/10.1080/10864415.2003.11044293

Hennig-Thurau, T., Gwinner, K. P., Walsh, G., \& Gremler, D. D. (2004). Electronic word-of-mouth via consumeropinion platforms: What motivates consumers to articulate themselves on the Internet? Journal of Interactive Marketing, 18, 38-52. https://doi.org/10.1002/dir.10073

Hovland. (1948). Social Communication. Social Communication., 92(5), 371-375. http://www.jstor.org/stable/3143048

Huete-Alcocer, N. (2017). A Literature Review of Word of Mouth and Electronic Word of Mouth: Implications for Consumer Behavior. Frontiers in Psychology, 8, 1256. https://doi.org/10.3389/fpsyg.2017.01256

Hussain, S., Ahmed, W., Jafar, R. M. S., Rabnawaz, A., \& Jianzhou, Y. (2017). eWOM source credibility, perceived risk, and food product customer's information adoption. Computers in Human Behavior, 66, 96-102. https://doi.org/10.1016/j.chb.2016.09.034

Hussain, S., Guangju, W., Jafar, R. M. S., Ilyas, Z., Mustafa, G., \& Jianzhou, Y. (2018). Consumers' online information adoption behavior: Motives and antecedents of electronic word of mouth communications. Computers in Human Behavior, 80, 22-32. https://doi.org/10.1016/j.chb.2017.09.019

Luca, M., \& Zervas, G. (2016). Fake it till you make it: Reputation, competition, and yelp review fraud. Management Science, 62(12), 3412-3427. https://doi.org/10.1287/mnsc.2015.2304

Munzel, A. (2016). Assisting consumers in detecting fake reviews: The role of identity information disclosure and consensus. Journal of Retailing and Consumer Services, 32, 96-108. https://doi.org/10.1016/j.jretconser.2016.06.002

Nakayama, M., \& Wan, Y. (2017). Exploratory study on anchoring: Fake vote counts in consumer reviews affect judgments of information quality. Journal of Theoretical and Applied Electronic Commerce Research, 
$12(1)$.

https://doi.org/10.4067/S0718-18762017000100002

Petty, R. E., \& Cacioppo, J. T. (1986). The Elaboration Likelihood Model of Persuasion. Communication and Persuasion, 19, 1-24. https://doi.org/10.1007/978-1-4612-4964-1_1

Shen, X. L., Cheung, C. M. K., \& Lee, M. K. O. (2013). What leads students to adopt information from Wikipedia? An empirical investigation into the role of trust and information usefulness. British Journal of Educational Technology, 44(3), 502-517. https://doi.org/10.1111/j.1467-8535.2012.01335.x

Sher, P. J., \& Lee, S.-H. (2009). Consumer Skepticism and Online Reviews: An Elaboration Likelihood Model Perspective. Social Behavior and Personality, 37(1), 137-144. https://doi.org/10.2224/sbp.2009.37.1.137

Sussman, S. W., \& Siegal, W. S. (2003). Informational Influence in Organizations: An Integrated Approach to Knowledge Adoption. Information Systems Research, 14(1), 47-65. https://doi.org/10.1287/isre.14.1.47.14767

Tamar, W. (2016). Are fake online reviews killing consumer confidence? - Marketing Land. Retrieved April 6, 2018, from https://marketingland.com/fake-online-reviews- killing-consumer-confidence-194239

Tseng, S. Y., \& Wang, C. N. (2016). Perceived risk influence on dual-route information adoption processes on travel websites. Journal of Business Research, 69(6), 2289-2296. https://doi.org/10.1016/j.jbusres.2015.12.044

Venkatesh, V., \& Bala, H. (2008). Technology Acceptance Model 3 and a Research Agenda on Interventions. Decision Sciences, 39(2), 273-315. https://doi.org/10.1111/j.1540-5915.2008.00192.x

Wang, Y. (2018). Online Purchase Intention Based on TAM and IAM: A Literature Review. International Journal of E-Education, e-Business, e-Management and $e$ Learning, 8(2), 66-73. https://doi.org/10.17706/ijeeee.2018.8.2.66-73

Zhang, X., Ko, M., \& Carpenter, D. (2016). Development of a scale to measure skepticism toward electronic word-of-mouth. Computers in Human Behavior, 56, 198-208. https://doi.org/10.1016/j.chb.2015.11.042

Zhao, Y., Yang, S., Narayan, V., \& Zhao, Y. (2013). Modeling Consumer Learning from Online Product Reviews. Marketing Science, 32(1), 153-169. https://doi.org/10.1287/mksc.1120.0755 